\title{
Splanchnic Extraction and Interconversion of Testosterone and Androstenedione in Man*
}

\author{
Marco A. Rivarola, Robert T. Singleton, and Claude J. Migeon $\neq$ \\ (From the Harriet Lane Service of The Children's Medical and Surgical Center, The Johns \\ Hopkins Hospital and University, and from the Department of Medicine, Division of \\ Cardiology, University of Maryland Hospital, Baltimore, Maryland)
}

\begin{abstract}
A constant infusion of ${ }^{3} \mathrm{H}$-testosterone and ${ }^{14} \mathrm{C}$-androstenedione was administered to four human subjects, two males and two females, until the concentrations of radioactive testosterone and androstenedione in systemic plasma became constant. At that time the concentrations of radioactive testosterone and androstenedione in hepatic vein plasma were determined. Splanchnic extraction of testosterone and androstenedione and the contribution of the splanchnic system to the blood interconversion of testosterone and androstenedione were calculated.

Androstenedione is extracted by the splanchnic system more efficiently than testosterone since $82.3 \%$ of androstenedione and $44 \%$ of testosterone were removed from the plasma after one passage.

The fraction of testosterone entering the splanchnic system that is transferred to blood androstenedione was 0.011 and the maximum possible transfer due to recirculation was 0.026 . This was $28 \%$ of the total blood transfer from testosterone to androstenedione. The fraction of androstenedione entering the splanchnic system that is transferred to blood testosterone after one passage was 0.005 , whereas the maximum possible transfer in this system was 0.006 . This represented only $16 \%$ of the total transfer from androstenedione to testosterone. Therefore, a large fraction of the interconversion of testosterone and androstenedione in vivo occurs outside the splanchnic system.
\end{abstract}

\section{Introduction}

There is strong evidence indicating that the liver plays an important role in the clearance of steroids from blood. It is particularly rich in enzymes active in steroid catabolism, as shown by in vitro incubations and perfusion studies $(1,2)$. Furthermore, it has been observed that the half-life of

* Received for publication 5 June 1967 and in revised form 4 August 1967.

Supported by U. S. Public Health Service Research Grant AM-00180 and Research Career Award K6-AM-21, 855 (CJM), and by the John Simon Guggenheim Foundation and Consejo Nacional de Investigaciones Cientificas y Tecnicas of Argentina (MAR).

$¥$ Address requests for reprints to Dr. Claude J. Migeon, CMSC 3-110, The Johns Hopkins Hospital, Baltimore, Md. 21205. steroids such as cortisol and aldosterone is prolonged in liver disease (3-5). Steroid extraction by the liver does not depend only on the enzymatic activity of the hepatic cell, but also on the amount of steroid presented to intracellular enzymes (6). This in turn is influenced by hepatic blood flow and by steroid binding to plasma proteins. An inverse correlation between degree of protein binding and plasma clearance has been reported for cortisol (6-10). If the clearance of testosterone $(\mathrm{T})$ and androstenedione $(\Delta)^{1}$ from blood is due mainly to the liver, a relation should be found between these clearances and the hepatic extraction of the two androgens. Since the metabolic

\footnotetext{
1 Testosterone $(T)=17 \beta$-hydroxyandrost-4-en-3-one; Androstenedione $(\Delta)=$ androst-4-ene-3, 17-dione.
} 
clearance rate $(\mathrm{MCR})^{2}$ of $\mathrm{T}$ is smaller than that of $\Delta(11,12)$, we should expect an hepatic extraction of $\Delta$ greater than that of T. Horton and Tait (11) studied the role of the splanchnic organs in the metabolism of $\mathrm{T}$ and $\Delta$ in four subjects by infusion of ${ }^{14} \mathrm{C}-\Delta$ at a constant rate through a nasogastric tube inserted into the lower stomach. Two of these subjects received, simultaneously, a constant infusion of ${ }^{3} \mathrm{H}-\mathrm{T}$ intravenously. The investigators reported that only $6.3 \%$ of the orally infused $\Delta$ entered the general circulation as $\Delta$, and they calculated indirectly that most of the conversion of $\Delta$ into $\mathrm{T}$ was extrasplanchnic (11).

In the present study, four subjects were given a constant intravenous infusion of ${ }^{3} \mathrm{H}-\mathrm{T}$ and ${ }^{14} \mathrm{C}-\Delta$. When the concentration of radioactivity of the two androgens in peripheral vein plasma (or right atrium plasma) had become constant, the concentration of radioactivity in hepatic vein plasma was also determined. Our findings are reported in this paper.

\section{Methods}

The following experimental subjects were studied.

No. 1, G. L., male, $18 \mathrm{yr}$, wt, $68 \mathrm{~kg}$, height, $175 \mathrm{~cm}$.

No. 2, J. W., male, $49 \mathrm{yr}$, wt, $75 \mathrm{~kg}$, height, $172 \mathrm{~cm}$.

No. 3, M. T., female, $25 \mathrm{yr}, \mathrm{wt}, 53 \mathrm{~kg}$, height, $148 \mathrm{~cm}$.

No. 4, M. C., female, $46 \mathrm{yr}$, wt, $55 \mathrm{~kg}$, height, $157 \mathrm{~cm}$.

In subjects 2,3 , and 4 , samples were collected during cardiac catheterization for diagnostic purposes. These samples were selected because they had well compensated lesions without cardiac insufficiency, along with entirely normal liver and kidney functions. Subject G. L. was a normal volunteer. We obtained permission for the study from the patients or the parents, as requested by the institutions involved.

A simultaneous constant infusion of ${ }^{8} \mathrm{H}-\mathrm{T}$ and ${ }^{14} \mathrm{C}-\Delta$ was administered by means of a technique described previously (12). At time zero, a priming dose of 3-5 $\mu \mathrm{c}$ of ${ }^{8} \mathrm{H}-\mathrm{T}$ and $2-4 \mu \mathrm{c}$ of ${ }^{14} \mathrm{C}-\Delta$ dissolved in $20 \mathrm{ml}$ of normal saline solution was injected intravenously. $20 \mathrm{~min}$ later, a constant infusion of these two radioactive steroids was given for at least $70 \mathrm{~min}$. The rate of the infusion was $0.4 \mathrm{ml} / \mathrm{min}\left(0.03-0.05 \mu \mathrm{c}\right.$ of ${ }^{3} \mathrm{H}-\mathrm{T}$ and $0.02-0.04 \mu \mathrm{c}$ of ${ }^{14} \mathrm{C}-\Delta / \mathrm{min}$. Blood samples $(40 \mathrm{ml}$ each) were taken from a peripheral vein $10 \mathrm{~min}$ before time zero and at different intervals during the constant infusion. In some instances, the periphreal vein sample was replaced by a sam-

\footnotetext{
${ }^{2}$ Metabolic clearance rate $(\mathrm{MCR})=\frac{\mathrm{R}}{\mathrm{C}_{\mathrm{r}}} \times 1.44 ; \mathrm{R}=$ rate of radioactive infusion in $\mathrm{cpm} / \mathrm{min} ; \mathrm{C}_{\mathrm{r}}=$ plasma radioactive concentrations in $\mathrm{cpm} / \mathrm{ml}$ at equilibrium; Production rate in blood $(\mathrm{PB})=\mathrm{MCR} \times \mathrm{C} ; \mathrm{C}=$ plasma hormone concentration in $\mathrm{mg} / \mathrm{liter}$.
}

ple obtained with a catheter placed in the right atrium. At time $60 \mathrm{~min}$ or later, a catheter was inserted into a femoral vein and brought up into the hepatic vein where blood samples were collected. The location of the catheter was determined by its position shown by X-ray and by oximetry. In patient G. L., a blood sample was also obtained from the renal vein. To avoid dilution of the blood, the first $5 \mathrm{ml}$ of all samples taken with the catheter were discarded.

The determination of the amount of radioactivity in plasma $T$ and $\Delta$ was performed in the samples collected during the constant infusion according to a technique published elsewhere (12).

The concentration of $\mathrm{T}$ and $\Delta$ in peripheral vein plasma was determined by using a double isotope derivative technique described previously (13).

\section{Calculations}

$\mathrm{MCR}, \mathrm{PB}$, and interconversion between $\mathrm{T}$ and $\Delta$ were calculated as described by Tait (14) and Horton and Tait (11). Splanchnic extraction (SE) ${ }^{3}$ was determined using Fick's principle (6) :

Difference in concentration in

$\mathrm{SE}=\frac{\text { afferent and efferent plasma }}{\text { Concentration in afferent supply }}$.

3 Definition of terms used subsequently:

SE $\left({ }^{3} \mathrm{H}-\mathrm{T}\right)$, splanchnic extraction of ${ }^{3} \mathrm{H}-\mathrm{T}$

SE $\left({ }^{14} \mathrm{C}-\Delta\right)$, splanchnic extraction of ${ }^{14} \mathrm{C}-\Delta$

${ }^{3} \mathrm{H}-\mathrm{T}_{\mathrm{B}}$, concentration of ${ }^{3} \mathrm{H}-\mathrm{T}$ in peripheral vein blood

${ }^{3} \mathrm{H}-\mathrm{T}_{\mathrm{s}}$, concentration of ${ }^{3} \mathrm{H}-\mathrm{T}$ in hepatic vein blood

${ }^{14} \mathrm{C}-\mathrm{T}_{\mathrm{B}}$, concentration of ${ }^{14} \mathrm{C}-\mathrm{T}$ in peripheral vein blood

${ }^{14} \mathrm{C}-\mathrm{T}_{\mathrm{S}}$, concentration of ${ }^{14} \mathrm{C}-\mathrm{T}$ in hepatic vein blood for $\Delta$

${ }^{14} \mathrm{C}-\Delta_{\mathbf{B}},{ }^{14} \mathrm{C}-\Delta_{\mathbf{S}},{ }^{3} \mathrm{H}-\Delta_{\mathbf{B}},{ }^{3} \mathrm{H}-\Delta_{\mathbf{S}}$ are equivalent expressions

$\rho_{\mathrm{BB}}{ }^{\mathrm{T} \Delta}$, transfer constant from blood $\mathrm{T}$ to blood $\Delta$

$\rho S^{T \Delta}$, transfer constant from splanchnic $T$ to blood $\Delta$

$\rho_{\mathrm{BB}} \Delta \mathrm{T}$, transfer constant from blood $\Delta$ to blood $\mathrm{T}$

$\rho_{\mathrm{SB}} \Delta \mathrm{T}$, transfer constant from splanchnic $\Delta$ to blood T

From this formula, the splanchnic extraction of $\mathrm{T}$ will be:

$$
\text { SE }\left({ }^{3} \mathrm{H}-\mathrm{T}\right)=\frac{{ }^{3} \mathrm{H}-\mathrm{T}_{\mathrm{B}}-{ }^{3} \mathrm{H}-\mathrm{T}_{\mathrm{S}}}{{ }^{3} \mathrm{H}-\mathrm{T}_{\mathrm{B}}}=1-\frac{{ }^{3} \mathrm{H}-\mathrm{T}_{\mathrm{S}}}{{ }^{3} \mathrm{H}-\mathrm{T}_{\mathrm{B}}} .
$$

However, in the present study, the above formula is not entirely correct, since a fraction of ${ }^{3} \mathrm{H}-\Delta_{B}$ entering the splanchnic pool will leave this pool as ${ }^{3} \mathrm{H}-\mathrm{T}$ and must therefore be subtracted from ${ }^{3} \mathrm{H}-\mathrm{T}_{\mathrm{s}}$ :

$$
\mathrm{SE}\left({ }^{3} \mathrm{H}-\mathrm{T}\right)=1-\frac{{ }^{3} \mathrm{H}-\mathrm{T}_{\mathrm{S}}-{ }^{3} \mathrm{H}-\Delta_{\mathrm{B}} \times \rho_{\mathrm{SB}} \Delta \mathrm{T}}{{ }^{3} \mathrm{H}-\mathrm{T}_{\mathrm{B}}},
$$

since

$$
{ }^{3} \mathrm{H}-\Delta_{B}={ }^{3} \mathrm{H}-\mathrm{T}_{B} \times \rho_{B B}{ }^{\mathrm{T} \Delta} .
$$

Substituting in equation [2]

$$
\mathrm{SE}\left({ }^{3} \mathrm{H}-\mathrm{T}\right)=1-\frac{{ }^{3} \mathrm{H}-\mathrm{T}_{\mathrm{B}}}{{ }^{3} \mathrm{H}-\mathrm{T}_{\mathrm{B}}}+\rho_{\mathrm{BB}}{ }^{\mathrm{T} \Delta} \times \rho_{\mathrm{BB}}{ }^{\Delta \mathrm{T}} .
$$

In equation [4], $\rho_{\mathrm{BB}}^{\mathrm{T} \Delta} \times \rho_{\mathrm{SB}}^{\Delta \mathrm{T}}$ is negligible and Fick's principle can be applied in the present case. Similarly:

$$
\mathrm{SE}\left({ }^{14} \mathrm{C}-\Delta\right)=1-\frac{{ }^{14} \mathrm{C}-\Delta_{\mathrm{S}}}{{ }^{14} \mathrm{C}-\Delta_{\mathrm{B}}}+\rho_{\mathrm{BB}} \Delta \mathrm{T} \times \rho_{\mathrm{SB}}{ }^{\mathrm{T}},
$$

in which $\rho_{\mathrm{BB}}{ }^{\mathrm{T}} \times \rho_{\mathrm{BB}}^{\mathrm{T} \Delta}$ is also negligible. 
TABLE I

Concentrations of radioactive testosterone and androstenedione in peripheral and hepatic vein plasma

\begin{tabular}{|c|c|c|c|c|c|c|c|c|c|c|c|}
\hline \multirow[t]{3}{*}{ Subject } & \multirow[t]{3}{*}{$\operatorname{Sex}$} & & & \multicolumn{4}{|c|}{$\begin{array}{l}\text { Peripheral vein or right atrium, } \\
\text { plasma concentration }\end{array}$} & \multicolumn{4}{|c|}{$\begin{array}{l}\text { Hepatic vein, } \\
\text { plasma concentration }\end{array}$} \\
\hline & & \multicolumn{2}{|c|}{ Rate of infusion } & \multicolumn{2}{|c|}{ Testosterone } & \multicolumn{2}{|c|}{ Androstenedione } & \multicolumn{2}{|c|}{ Testosterone } & \multicolumn{2}{|c|}{ Androstenedione } \\
\hline & & ${ }^{2} \mathrm{H}-\mathrm{T}$ & ${ }^{14 C-\Delta}$ & ${ }^{3} \mathrm{H}$ & ${ }^{14} \mathrm{C}$ & ${ }^{3} \mathrm{H}$ & ${ }^{14} \mathrm{C}$ & ${ }^{3} \mathrm{H}$ & ${ }^{14} \mathrm{C}$ & ${ }^{8} \mathrm{H}$ & ${ }^{14} \mathrm{C}$ \\
\hline & & \multicolumn{2}{|c|}{$c p m / \min$} & \multicolumn{4}{|c|}{$c p m / 100 \mathrm{ml}$} & \multicolumn{4}{|c|}{$c p m / 100 m l$} \\
\hline $\begin{array}{l}\text { No. } 1 \\
\text { No. } 2 \\
\text { No. } 3 \\
\text { No. } 4\end{array}$ & $\begin{array}{l}\mathrm{M} \\
\mathrm{M} \\
\mathrm{F} \\
\mathrm{F}\end{array}$ & $\begin{array}{l}20,221 \\
66,577 \\
36,204 \\
57,638\end{array}$ & $\begin{array}{l}19,804 \\
37,195 \\
37,672 \\
53,925\end{array}$ & $\begin{array}{r}4,200 \\
12,900 \\
8,930 \\
14,300\end{array}$ & $\begin{array}{l}200 \\
294 \\
295 \\
472\end{array}$ & $\begin{array}{l}220 \\
667 \\
414 \\
275\end{array}$ & $\begin{array}{l}1,760 \\
4,160 \\
4,210 \\
7,310\end{array}$ & $\begin{array}{l}2,240 \\
6,150 \\
5,260 \\
9,270\end{array}$ & $\begin{array}{l}134 \\
145 \\
172 \\
338\end{array}$ & $\begin{array}{r}83 \\
205 \\
212 \\
231\end{array}$ & $\begin{array}{r}144 \\
848 \\
1,170 \\
1,080\end{array}$ \\
\hline
\end{tabular}

Transfer constant from the splanchnic pool to the blood pool

The fraction of $\Delta$ entering the splanchnic pool that is transferred to blood $\mathrm{T}\left(\rho_{\mathrm{BB}} \Delta \mathrm{T}\right)$ and the fraction of $\mathrm{T}$ transferred to blood $\Delta\left(\rho \mathrm{SB}^{\mathrm{T} \Delta}\right)$ have been calculated according to the following equations (see Appendix):

$$
\begin{aligned}
& \rho_{\mathrm{SB}}{ }^{\Delta T}=\frac{{ }^{14} \mathrm{C}-\mathrm{T}_{\mathrm{S}}-{ }^{14} \mathrm{C}-\mathrm{T}_{\mathrm{B}} \times{ }^{3}{ }^{3} \mathrm{H}-\mathrm{T}_{\mathrm{B}}}{{ }^{14} \mathrm{C}-\mathrm{T}_{\mathrm{B}}} \\
& \times \frac{1}{1-\frac{{ }^{14} \mathrm{C}-\mathrm{T}_{\mathrm{B}} \times{ }^{3} \mathrm{H}-\Delta_{\mathrm{B}}}{{ }^{14} \mathrm{C}-\Delta_{\mathrm{B}} \times{ }^{3} \mathrm{H}-\mathrm{T}_{\mathrm{B}}}}
\end{aligned}
$$

and

$$
\rho_{\mathrm{SB}}{ }^{\mathrm{T}} \Delta=\frac{{ }^{3} \mathrm{H}-\Delta_{\mathrm{B}}-{ }^{3} \mathrm{H}-\Delta_{\mathrm{B}} \times \frac{{ }^{14} \mathrm{C}-\Delta_{\mathrm{S}}}{{ }^{14} \mathrm{C}-\Delta_{\mathrm{B}}}}{{ }^{3} \mathrm{H}-\mathrm{T}_{\mathrm{B}}} \times \frac{1}{1-\frac{{ }^{14} \mathrm{C}-\mathrm{T}_{\mathrm{B}} \times{ }^{3} \mathrm{H}-\Delta_{\mathrm{B}}}{{ }^{14} \mathrm{C}-\Delta_{\mathrm{B}} \times{ }^{3} \mathrm{H}-\mathrm{T}_{\mathrm{B}}}} .
$$

However, some of the $T$ and $\Delta$ entering the splanchnic circulation will eventually return to the liver and further interconversion will occur. A maximum value for the transfer (maximum transfer) can be calculated from the SE and the $\rho_{\text {SB }}$ value, assuming no extra splanchnic extraction (see Appendix):

$$
\text { Maximum transfer }=\rho \mathrm{BB} \times \frac{1}{\mathrm{SE}} .
$$

If there were significant extrasplanchnic extraction present, the splanchnic interconversion due to recirculation would be lower than the value of maximum transfer.

\section{Results}

Plasma concentration of radioactivity in $T$ and $\Delta$ during the constant infusion. The concentrations of ${ }^{3} \mathrm{H}$ and ${ }^{14} \mathrm{C}$ radioactivity in $\mathrm{T}$ and $\Delta$ in peripheral vein (or right atrium) plasma are presented in Table I. The values shown represent the mean of three different samples except for patients 3 and 4, from whom only two samples were collected. The concentrations in the hepatic vein samples are also shown in Table I. These samples were always obtained just before the last peripheral vein sample. The $\mathrm{PB}(\mathrm{T})$ and $\mathrm{PB}(\Delta)$ and transfer constant of subject 1 have already been published elsewhere (12).

Splanchnic extraction, metabolic clearance rate, plasma concentration, and blood production of $T$ and $\Delta$. Mean percentage extraction after one passage through the splanchnic system was 44.0 for $\mathrm{T}$ and 82.3 for $\Delta$. MRC, plasma concentrations, and $\mathrm{PB}$ rates for $\mathrm{T}$ and $\Delta$ are shown in Table II. The plasma concentration of $\Delta$ in patient 2 was unexpectedly high. This determination was confirmed in a second aliquot of the same plasma sample.

Renal extraction and interconversion of $T$ and $\Delta$ in subject $G$. $L$. In subject G. L. (No. 1 ), the plasma concentration of radioactivity in $\mathrm{T}$ and $\Delta$ in the right renal vein was determined during equilibrium. The following results were obtained: ${ }^{3} \mathrm{H}-\mathrm{T} 3780,{ }^{14} \mathrm{C}-\mathrm{T} 148,{ }^{3} \mathrm{H}-\Delta \quad 224,{ }^{14} \mathrm{C}-\Delta 1780$ $\mathrm{cpm} / 100 \mathrm{ml}$ of plasma. These values are not significantly different from those found in the peripheral vein samples, which suggests the absence of extraction and interconversion of $\mathrm{T}$ and $\Delta$ by the right kidney of this patient.

\begin{tabular}{|c|c|c|c|c|c|c|c|c|}
\hline \multirow[b]{2}{*}{ Subject } & \multicolumn{2}{|c|}{$\begin{array}{l}\text { Splanchnic } \\
\text { extraction }\end{array}$} & \multicolumn{2}{|c|}{$\begin{array}{c}\text { MCR } \\
\text { (1/day) }\end{array}$} & \multicolumn{2}{|c|}{$\begin{array}{l}\text { Concen- } \\
\text { tration in } \\
\text { plasma }\end{array}$} & \multicolumn{2}{|c|}{ PB } \\
\hline & $T$ & $\Delta$ & $\mathrm{T}$ & $\Delta$ & $\mathrm{T}$ & $\Delta$ & $\mathrm{T}$ & $\Delta$ \\
\hline & \multicolumn{2}{|c|}{$\%$} & & & \multicolumn{2}{|c|}{$\begin{array}{c}m \mu \mathrm{g} / \\
100 \mathrm{ml}\end{array}$} & \multicolumn{2}{|c|}{$m g / d a y$} \\
\hline No. 1 & 47.1 & 92.0 & 695 & 1,620 & 917 & 130 & 6.4 & 2.1 \\
\hline No. 2 & 52.3 & 79.6 & 743 & 1,287 & 802 & 597 & 5.9 & 7.7 \\
\hline No. 3 & 41.6 & 72.2 & 583 & 1,288 & 58 & 305 & 0.34 & 3.9 \\
\hline No. 4 & 35.2 & 85.6 & 580 & 1,062 & $*$ & $*$ & $*$ & * \\
\hline Mean & 44.0 & 82.3 & & & & & & \\
\hline
\end{tabular}

TABLE II

Splanchnic extraction, metabolic clearance rate, plasma concentration, and blood production rates of testosterone and androstenedione

* Not determined. 
TABLE III

In vivo interconversion of testosterone and androstenedione

\begin{tabular}{|c|c|c|c|c|c|c|}
\hline & {$[\rho]_{\mathrm{BB}} \mathrm{T} \Delta$} & $\rho \mathrm{BB}^{\mathrm{T}} \Delta$ & 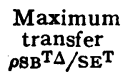 & {$[\rho]_{\mathrm{BB}} \Delta \mathrm{T}$} & $\rho \mathrm{SB} \Delta \mathrm{T}$ & $\begin{array}{c}\text { Maximum } \\
\text { transfer } \\
\rho \mathrm{SB}^{\Delta \mathrm{T}} / \mathrm{SE}\end{array}$ \\
\hline No. 1 & 0.126 & 0.015 & 0.032 & 0.046 & 0.017 & 0.018 \\
\hline No. 2 & 0.086 & 0.005 & 0.010 & 0.041 & 0.001 & 0.001 \\
\hline No. 3 & 0.120 & 0.011 & 0.026 & 0.031 & 0.000 & 0.000 \\
\hline No. 4 & 0.035 & 0.013 & 0.036 & 0.035 & 0.004 & 0.005 \\
\hline Mean & 0.092 & 0.011 & 0.026 & 0.038 & 0.005 & 0.006 \\
\hline
\end{tabular}

Comparison between over-all peripheral and splanchnic interconversion of $T$ and $\Delta$ (Table III). The mean over-all conversion rate between blood $\mathrm{T}$ and blood $\Delta\left([\rho]_{\mathbf{B B}}^{\mathbf{T} \Delta}\right)$ was 0.092 . On the other hand, mean conversion rate between splanchnic $T$ and blood $\Delta\left(\rho_{\mathrm{SB}}{ }^{\mathrm{T} \Delta}\right)$ was 0.011 and mean maximum transfer due to recirculation 0.026 . Therefore no more than $28 \%(0.026 / 0.092 \times 100)$ of the conversion of blood $\mathrm{T}$ to blood $\Delta$ occurs inside the splanchnic system.

Similarly, mean overall conversion rate between blood $\Delta$ and blood $\mathrm{T}\left([\rho]_{\mathrm{BB}}{ }^{\Delta \mathrm{T}}\right)$ was 0.038 , whereas mean conversion rate between splanchnic $\Delta$ and blood $\mathrm{T}\left(\rho_{\mathrm{SB}}{ }^{\Delta \mathrm{T}}\right)$ was 0.005 . Since mean maximum transfer due to recirculation in the splanchnic area was only 0.006 , no more than $16 \%$ $(0.006 / 0.038 \times 100)$ of the conversion of blood $\Delta$ to blood $\mathrm{T}$ occurs in the splanchnic compartment.

\section{Discussion}

Horton and Tait have reported an average $\operatorname{MCR}(\mathrm{T})$ for three male subjects of 1110 liters/ day, and an average for two females of 885 liters/ day. With a similar method, our averages for four males and four females were 1188 and 592 liters/day, respectively. Southren et al. (15), using the single injection technique, found a mean $\operatorname{MCR}(\mathrm{T})$ of 1872 in four normal males and a mean of 738 liters/day in three normal females. Southren and coworkers (16), using the constant infusion technique, have recently reported values (mean $\pm \mathrm{SD}$ ) of $1288 \pm 221$ liters/day in six males, and values of $675 \pm 139$ liters/day in six females. The difference in values of males and females may be due to an inherent sex difference or to a difference in body size between the two sexes. One inherent sex difference might be the slightly, but significantly greater, binding of $\mathrm{T}$ to plasma proteins found in females (unpullished observation). Horton and Tait (11) have reported $\operatorname{MCR}(\Delta)$ values of 2330 liters/day in 12 subjects, which show no great difference between males and females. Although we have observed a similar average in four adult males (2200 liters/day), our average $\operatorname{MCR}(\Delta)$ for four normal females was lower and ranged from 1230 to 1385 liters/day.

The two female subjects of the present study had $\operatorname{MCR}(\mathrm{T})$ and $\operatorname{MCR}(\Delta)$ values similar to those of our normal female subjects. On the other hand, the $\operatorname{MCR}(\mathrm{T})$ and $\operatorname{MCR}(\Delta)$ of the two male subjects were definitely lower than our control values. Subject 1 was a normal male, whereas subject 2 who was submitted to cardiac catheterization for diagnostic purposes had normal liver function tests. Anesthesia and surgical stress can decrease liver blood flow and can alter liver function as well. It is possible that the over-all stress related to the catheterization can produce a certain degree of liver disturbance in some subjects.

Our data indicate that $44 \%$ of $\mathrm{T}$ and $82.3 \%$ of $\Delta$ are removed from the circulation after one passage through the splanchnic system. According to generally accepted concepts, this extraction probably occurs in the liver. If there were no extrahepatic extraction, the metabolic clearance rate of $\mathrm{T}$ and $\Delta$ should be 44 and $82.3 \%$ of the hepatic plasma flow. Since the hepatic plasma flow was not determined in our subjects, the existence and extent of extrahepatic removal cannot be established. Horton and Tait (11) have assumed an hepatic plasma flow of 1600 liters/day, and they have concluded that at least one-third of the metabolism of $\Delta$ was extrahepatic. However, the large variations in hepatic plasma flow among subjects make such calculations very approximate.

Transfer constants between blood $\mathrm{T}$ and blood $\Delta$ pools are calculated from the ratio of the plasma concentrations of one isotope in $\mathrm{T}$ and $\Delta$, and the ratio of their $\operatorname{MCR}(11,13)$. In this study, we have also calculated the transfer constants from the splanchnic pool of $\Delta$ or $\mathrm{T}$ to the blood pool of $\mathrm{T}$ or $\Delta$, respectively. Constants were determined from the concentrations of both isotopes in the two steroids in peripheral and hepatic vein plasma. Since the splanchnic to blood, and blood to blood transfer constants were determined simultaneously, we have had the opportunity of establishing quanti- 
tatively the role of the splanchnic system in this interconversion.

We have concluded that, on the average, not more than $28 \%$ of the total conversion of blood $\mathrm{T}$ to blood $\Delta\left([\rho]_{\mathbf{S B}^{\mathrm{T}}}^{\mathrm{T} \Delta}\right)$ occurs in the splanchnic system. The fact that one of the four subjects, patient 4 , had a maximum transfer ${ }_{\mathbf{S B}}{ }^{\mathrm{T} \Delta}$ equal to the over-all blood transfer, $[\rho]_{\mathbf{B B}}{ }^{\mathrm{T} \Delta}$ does not exclude the presence of extrasplanchnic transfer in this individual; the value of maximum transfer $\mathbf{S B}^{\mathrm{T} \Delta}$ represents the greatest theoretically possible transfer from the splanchnic system to blood, in the absence of extrasplanchnic extraction, and does not necessarily represent the actual splanchnic transfer.

Similarly, not more than $16 \%$ of the total conversion of blood $\Delta$ to blood $T$ occurs in the splanchnic system. Horton and Tait, using a different approach (11), have reported that $30 \%$ of the total conversion of blood $\Delta$ to blood $\mathrm{T}$ took place in the splanchnic system. Although this result is twice our value of $16 \%$, a similar conclusion must be reached, i.e., a major fraction of the interconversion of $\Delta$ to $\mathrm{T}$ in blood occurs outside of the liver.

If one considers the specific case of our male subject, No. 1, the over-all contribution of $\mathrm{PB}(\mathrm{T})$ to $\mathrm{PB}(\Delta)$ was $0.81 \mathrm{mg} /$ day, but at least $86 \%$ of the conversion, or $0.7 \mathrm{mg} /$ day, took place outside of the splanchnic area. In this same subject, the over-all contribution of $\mathrm{PB}(\Delta)$ to $\mathrm{PB}(\mathrm{T})$ was 0.1 $\mathrm{mg} /$ day with at least $60 \%$ of the conversion $(0.06$ $\mathrm{mg} /$ day) extrasplanchnic. In our female patient, No. 3, the over-all contribution of $\mathrm{PB}(\mathrm{T})$ to $\mathrm{PB}$ $(\Delta)$ was $0.04 \mathrm{mg} /$ day with at least $78 \%$ of the conversion $(0.03 \mathrm{mg} /$ day $)$ extrasplanchnic, whereas the over-all contribution of $\mathrm{PB}(\Delta)$ to $\mathrm{PB}(\mathrm{T})$ was $0.1 \mathrm{mg} /$ day, all conversion taking place outside of the liver.

In vitro conversion of $T$ to $\Delta$ can be carried out by human red cells $(17,18)$ and human skin $(19)$, whereas conversion of $\Delta$ to $T$ has been observed in rabbit skeletal muscle (20). It is conceivable that these conversions could occur in vivo. It is of interest that we could not detect any significant extraction or interconversion of $\mathrm{T}$ and $\Delta$ by the kidney of one patient.

\section{Acknowledgments}

We wish to express our appreciation to Dr. James Tait for his advice, and to Dr. Gottlieb Friesinger for his help in studying one of the subjects. Thanks are also due to Mrs. Betty Lawrence and Miss Shirley Brantley for their technical assistance, and to Miss K. Scheller for her secretarial help.

\section{Appendix}

1. Three assumptions have been made for the calculation of the interconversion between $T$ and $\Delta$ in the splanchnic system: $(a)$ The concentrations of $\mathrm{T}$ and $\Delta$ in the peripheral vein sample are representative of the concentrations of $T$ and $\Delta$ entering the splanchnic circulation; $(b)$ The concentrations of $T$ and $\Delta$ in the hepatic vein sample are representative of the concentrations of $T$ and $\Delta$ leaving the splanchnic system; and $(c)$ The radioactivity of $T$ and $\Delta$ in hepatic vein blood will come only from $T$ and $\Delta$ entering the splanchnic area. Since the plasma flow entering the splanchnic pool equals the flow leaving the pool, concentrations are proportional to pool production rates. The fraction of ${ }^{14} \mathrm{C}-\Delta$ entering the splanchnic pool that leaves the pool as ${ }^{14} \mathrm{C}$ - $\mathrm{T}$ can be calculated by subtracting from the total ${ }^{14} \mathrm{C}-\mathrm{T}$ in hepatic vein plasma, the ${ }^{14} \mathrm{C}-\mathrm{T}$ leaving that pool and which had entered it as ${ }^{14} \mathrm{C}-\mathrm{T}$.

$$
\begin{aligned}
& \rho_{\mathrm{SB}} \Delta \mathrm{T}=\frac{{ }^{14} \mathrm{C}-\mathrm{T}_{\mathrm{B}}-{ }^{14} \mathrm{C}-\mathrm{T}_{\mathrm{B}} \times \frac{{ }^{3} \mathrm{H}-\mathrm{T}_{\mathrm{B}}-{ }^{3} \mathrm{H}-\Delta_{\mathrm{B}} \times \rho_{\mathrm{BB}} \Delta \mathrm{T}}{{ }^{3} \mathrm{H}-\mathrm{T}_{\mathrm{B}}}}{{ }^{14} \mathrm{C}-\Delta_{\mathrm{B}}} \\
& =\frac{{ }^{14} \mathrm{C}-\mathrm{T}_{\mathrm{S}}-\frac{{ }^{14} \mathrm{C}-\mathrm{T}_{\mathrm{B}} X^{3} \mathrm{H}-\mathrm{T}_{\mathrm{g}}}{{ }^{8} \mathrm{H}-\mathrm{T}_{\mathrm{B}}}+\frac{{ }^{14} \mathrm{C}-\mathrm{T}_{\mathrm{B}} X^{3} \mathrm{H}-\Delta_{\mathrm{B}} X_{\rho_{\mathrm{BB}}{ }^{\Delta T}}}{{ }^{8} \mathrm{H}-\mathrm{T}_{\mathrm{B}}}}{{ }^{14} \mathrm{C}-\Delta_{\mathrm{B}}}
\end{aligned}
$$

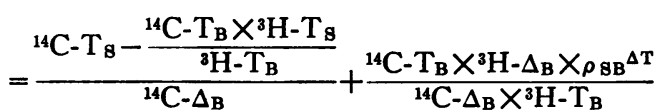

Solving for $\rho \mathrm{BB}^{\Delta \mathrm{T}}$ :

$$
\rho \mathrm{SB}^{\Delta \mathrm{T}}=\frac{{ }^{14} \mathrm{C}-\mathrm{T}_{\mathrm{B}}-{ }^{14} \mathrm{C}-\mathrm{T}_{\mathrm{B}} \times{ }^{{ }^{3} \mathrm{H}-\mathrm{T}_{\mathrm{B}}}}{{ }^{{ }^{14} \mathrm{C}-\mathrm{T}_{\mathrm{B}}}} \times \frac{1}{1-\frac{{ }_{\mathrm{B}}}{1{ }^{14} \mathrm{C}-\mathrm{T}_{\mathrm{B}} X^{3} \mathrm{H}-\Delta_{\mathrm{B}}}}
$$

Similarly:

$$
\rho_{\mathrm{SB}}{ }^{\mathrm{T}}=\frac{{ }^{8} \mathrm{H}-\Delta_{\mathrm{S}}-{ }^{3} \mathrm{H}-\Delta_{\mathrm{B}} \times{ }^{1{ }^{14} \mathrm{C}-\Delta_{\mathrm{g}}}}{{ }^{{ }^{3} \mathrm{H}-\mathrm{T}_{\mathrm{B}}}} \times \frac{1}{1-\frac{{ }^{14} \mathrm{C}-\mathrm{T}_{\mathrm{B}} X^{3} \mathrm{H}-\Delta_{\mathrm{B}}}{{ }^{14} \mathrm{C}-\Delta_{\mathrm{B}} X^{3} \mathrm{H}-\mathrm{T}_{\mathrm{B}}}}
$$

2. The transfer constants calculated in the manner outlined above represent the interconversion after one passage through the liver. If extrasplanchnic removal is insignificant, the fraction that escaped extraction will return to the splanchnic area and total conversion of $\Delta$ to $\mathrm{T}$ can be calculated as

$$
\begin{aligned}
\rho \mathrm{SB}^{\Delta \mathrm{T}} & +\rho \mathrm{BB}^{\Delta \mathrm{T}}\left(1-\mathrm{SE}^{\Delta}\right) \\
& +\rho \mathrm{BB}^{\Delta \mathrm{T}}\left(1-\mathrm{SE}^{\Delta}\right)^{2}+\cdots+\rho \mathrm{BB}^{\Delta \mathrm{T}}\left(1-\mathrm{SE}^{\Delta}\right)^{\mathrm{n}-1},
\end{aligned}
$$

or

$\rho \mathrm{SB}^{\Delta \mathrm{T}}\left[1+\left(1-\mathrm{SE}^{\Delta}\right)+\left(1-\mathrm{SE}^{\Delta}\right)^{2}+\cdots+\left(1-\mathrm{SE}^{\Delta}\right)^{\mathrm{n}-1}\right]$

The geometric series inside the brackets $(\mathrm{Sn})$ is convergent and reaches a limit:

$$
\underset{n \rightarrow \infty}{\operatorname{Lt}}=\frac{1}{1-\left(1-\mathrm{SE}^{\Delta}\right)}
$$

Therefore:

$$
\begin{aligned}
\rho \mathrm{SB}^{\Delta \mathrm{T}}\left[\frac{1}{1-\left(1-\mathrm{SE}^{\Delta}\right)}\right]=\rho \mathrm{SB}^{\Delta \mathrm{T}} & \frac{1}{\mathrm{SE}^{\Delta}} \\
& =\text { maximum transfer } \mathrm{BB}^{\Delta \mathrm{T}} .
\end{aligned}
$$


Similarly:

$$
\rho \mathrm{SB}^{\mathrm{T} \Delta} \frac{1}{\mathrm{SE}^{\mathrm{T}}}=\text { maximum } \operatorname{transfer}_{\mathrm{SB}^{\mathrm{T}}}^{\mathrm{T} \Delta} .
$$

\section{References}

1. Dorfman, R. I., and F. Ungar. 1965. Metabolism of Steroid Hormones. Academic Press Inc., New York. 289.

2. Samuels, L. T., and C. D. West. 1952. The intermediary metabolism of the non-benzenoid steroid hormones. Vitamins Hormones. 10: 251.

3. Peterson, R. E. 1960. Adrenocortical steroid metabolism and adrenal cortical function in liver disease. J. Clin. Invest. 39 : 320.

4. Coppage, W. S., Jr., D. P. Island, A. E. Cooner, and G. W. Liddle. 1962. The metabolism of aldosterone in normal subjects and in patients with hepatic cirrhosis. J. Clin. Invest. 41: 1672.

5. Yates, F. E., and J. Urquhart. 1962. Control of plasma concentrations of adrenocortical hormones. Phys. Rev. 42 : 359.

6. Tait, J. F., and S. Burstein. 1964. In The Hormones. G. Pincus, K. V. Thimann, and E. B. Astwood, editors. Academic Press Inc., New York. 5 : 441.

7. Peterson, R. E., G. Nokes, P. S. Chen, Jr., and R. L. Black. 1960. Estrogens and adrenocortical function in man. J. Clin. Endocrinol. Metab. $20: 495$.

8. Mills, I. H., H. P. Schedl, P. S. Chen, Jr., and F. C. Bartter. 1960. The effect of estrogen administration on the metabolism and protein binding of hydrocortisone. J. Clin. Endocrinol. Metab. 20: 515.

9. Wallace, E. Z., and A. C. Carter. 1960. Studies on the mechanism of the plasma 17-hydroxycorticosteroid elevation induced in man by estrogens. $J$. Clin. Invest. 39 : 601.

10. Sandberg, A. A., and W. R. Slaunwhite, Jr. 1959. Transcortin: a corticosteroid-binding protein of plasma. II. Levels in various conditions and the effects of estrogens. J. Clin. Invest. 38: 1290.

11. Horton, R., and J. F. Tait. 1966. Androstenedione production and interconversion rates measured in peripheral blood and studies on the possible site of its interconversion to testosterone. J. Clin. Invest. $45: 301$.
12. Rivarola, M. A., J. M. Saez, W. J. Meyer, M. E. Jenkins, and C. J. Migeon. 1966. Metabolic clearance rate and blood production rate of testosterone and androst-4-ene-3, 17-dione under basal conditions, ACTH and HCG stimulation. Comparison with urinary production rate of testosterone. $J$. Clin. Endocrinol. Metab. 26: 1208.

13. Rivarola, M. A., and C. J. Migeon. 1966. Determination of testosterone and androst-4-ene-3, 17-dione concentration in human plasma. Steroids. 7: 103.

14. Tait, J. F. 1963. Review: the use of isotopic steroids for the measurement of production rates in vivo. J. Clin. Endocrinol. Metab. 23: 1285.

15. Southren, A. L., S. Tochimoto, N. C. Carmody, and K. Isurugi. 1965. Plasma production rates of testosterone in normal adult men and women and in patients with the syndrome of feminizing testes. J. Clin. Endocrinol. Metab. $25: 1441$.

16. Southren, A. L., G. G. Gordon, S. Tochimoto, G. Pinzon, D. R. Lane, and W. Stypulkowski. 1967. Mean plasma concentration, metabolic clearance and basal plasma production rates of testosterone in normal young men and women using a constant infusion procedure: effect of time of day and plasma concentration on the metabolic clearance rate of testosterone. J. Clin. Endocrinol. Metab. 27: 686.

17. Portius, H. J., and K. Repke. 1960. Hydroxysteroid-Dehydrogenasen, $\Delta^{5}$-3-Ketosteroid-Isomerase und $\Delta^{4}$-Steroid-Hydrogenase in roten Blutzellen. Arch. Exptl. Pathol. Pharmakol. 239: 299.

18. Migeon, C. J., O. L. Lescure, W. H. Zinkham, and J. B. Sidbury, Jr. 1962. In vitro interconversion of $16-\mathrm{C}^{14}$-estrone and $16-\mathrm{C}^{14}$-estradiol-17 $\beta$ by erythrocytes from normal subjects and from subjects with a deficiency of red cell glucose-6-phosphate dehydrogenase activity. J. Clin. Invest. 41: 2025.

19. Wotiz, H. H., H. Mescon, H. Doppel, and H. M. Lemon. 1956. The in vitro metabolism of testosterone by human skin. J. Invest. Dermatol. 26: 113.

20. Thomas, P. Z., and R. I. Dorfman. 1964. Metabolism in vitro of androst-4-ene-3, 17-dione-4- ${ }^{14} \mathrm{C}$ by rabbit skeletal muscle strips. J. Biol. Chem. 239, 762. 